\title{
PENGARUH IMPLEMENTASI KEBIJAKAN JAMINAN KESEHATAN DAERAH TERHADAP KUALITAS PELAYANAN KESEHATAN MASYARAKAT MISKIN PADA DINAS KESEHATAN KOTA TASIKMALAYA
}

\section{Basuki Rahmat}

Sekolah Tinggi Ilmu Administrasi (STIA) YPPT Priangan Timur Tasikmalaya

Email: ukitasik@gmail.com

\begin{abstract}
Abstrak
Tujuan penelitian ini untuk mengetahui pengaruh implementasi kebijakan jaminan kesehatan daerah terhadap kualitas pelayanan kesehatan masyarakat miskin pada Dinas Kesehatan Kota Tasikmalaya. Metode penelitian yang digunakan adalah deskriptif analisis. Jumlah populasi sebanyak 67 orang pegawai yang terdiri dari 7 orang petugas di Dinas Kesehatan Kota Tasikmalaya, masing-masing 3 orang tiap puskesmas yang tersebar di 20 puskesmas Kota Tasikmalaya. Analisis data menggunakan analisis jalur (path analisis). Hasil penelitian menunjukkan bahwa implementasi kebijakan jaminan kesehatan daerah yang meliputi komunikasi, sumber daya, disposisi, dan struktur birokrasi menurut responden adalah sebesar 3520. Hal ini menunjukkan bahwa indikator-indikator dari implementasi kebijakan jaminan kesehatan daerah yang dilakukan oleh Dinas Kesehatan Kota Tasikmalaya sudah sesuai dengan prosedur yang ditetapkan oleh pemerintah pusat. Nilai yang diperoleh dari tanggapan responden mengenai kualitas pelayanan yang diberikan oleh petugas Dinas Kesehatan/Puskesmas Kota Tasikmalaya dalam memberikan pelayanan tentang jaminan kesehatan kepada masyarakat miskin menurut responden adalah sebesar 3030. Hal ini menunjukkan bahwa indikator-indikator dari kualitas pelayanan yang diberikan sudah sesuai yang diharapkan oleh masyarakat. Pengaruh implementasi Kebijakan (Komunikasi, Sumber daya, Disposisi, dan Struktur birokrasi) Terhadap Kualitas Pelayanan Kesehatan di Dinas Kesehatan Kota Tasikmalaya diperoleh pengaruh sebesar 0,494 atau 49,4\%, sedangkan pengaruh faktor luar yang tidak termasuk dalam variabel penelitian adalah sebesar 0,506 atau 50,6\%, dengan nila F hitung sebesar 15,128 dengan

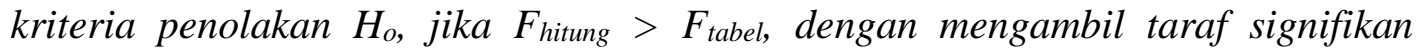
$\alpha$ sebesar $5 \%$, maka dari tabel distribusi $F$-Snedecor diperoleh $F \alpha ; k ;(n-k-1)=$ 67-2-1 adalah sebesar 1,34 atau cukup melihat sig $F$ yaitu 0,000 yang artinya dengan $\alpha$ lebih kecil dari $5 \%$ masih menunjukan signifikan.
\end{abstract}

Kata kunci: Kebijakan jaminan kesehatan, kualitas pelayanan kesehatan

\section{Pendahuluan}

Pembangunan dibidang kesehatan merupakan bagian dari pembangunan nasional, pemerintah sebagai institusi yang bertanggung jawab atas pemeliharaan kesehatan harus memenuhi kewajiban dalam menyediakan sarana pelayanan kesehatan. Pelayanan kesehatan pada dasarnya bertujuan untuk meningkatkan mutu kesehatan bagi seluruh masyarakat (Naldi, 2019). Kesehatan merupakan kebutuhan manusia yang 
utama dan menjadi prioritas yang mendasar bagi kehidupan. Pelaksanaan pembangunan di bidang kesehatan melibatkan seluruh warga masyarakat Indonesia hal tersebut dapat dimengerti karena pembangunan kesehatan mempunyai hubungan yang dinamis dengan sektor pembangunan lainnya.

Dalam Undang-Undang Dasar 1945 Pasal 28 H dan Undang-Undang Nomor 23 Tahun 1992 Pasal 4 tentang kesehatan, ditetapkan bahwa setiap orang berhak mendapatkan pelayanan kesehatan. Karena itu, setiap individu, keluarga dan masyarakat berhak memperoleh perlindungan terhadap kesehatannya, dan negara bertanggung jawab agar terpenuhinya hak hidup sehat bagi penduduknya termasuk bagi masyarakat miskin dan tidak mampu, kemudian pemerintah bekerja sama dengan pemerintah daerah dengan perangkat daerah yang disebut dengan Dinas Kesehatan kemudian Dinas Kesehatan mengalokasikan dana kepada pihak Rumah Sakit Daerah dan Puskesmas yang diberikan kepada masyarakat yang benar-benar tidak mampu, dengan persyaratan yang sudah ditentukan oleh pihak Dinas Kesehatan. Persyaratan yang dimaksud adalah warga/ masyarakat yang benar-benar miskin dan sudah terdata oleh pemerintah, memiliki kartu jamkesmas.

Program ini bertujuan untuk meningkatkan pelayanan kesehatan masyarakat miskin yang tidak mampu. Melalui pemeliharaan kesehatan masyarakat miskin itu diharapkan dapat menurunkan angka kematian ibu melahirkan, menurunkan angka kematian bayi dan balita serta penurunan angka kelahiran, disamping dapat terlayaninya kasus-kasus kesehatan masyarakat miskin umumnya (Keputusan Menteri Kesehatan No. 125/Menkes/SK/II/2008 Tanggal 6 Pebruari 2008 Tentang Pedoman Pelaksanaan Jaminan Kesehatan Masyarakat).

Begitu juga yang terjadi di Kota Tasikmalaya, melalui Peraturan Walikota Tasikmalaya Nomor 67 Tahun 2014 Tentang Jaminan Kesehatan Daerah (JAMKESDA)), masyarakat miskin yang ditetapkan dengan Surat Keputusan Walikota Tasikmalaya adalah Jamkesmas 183.197 jiwa dan Jamkeskinda 53.364 jiwa. Pemerintah Kota Tasikmalaya tahun 2013 mendapatkan kuota Jaminan Asuransi Kesehatan Masyarakat (Jamkesmas) sebanyak 228.000, sementara jumlah warga miskin mencapai 240.093 orang, dengan kuota tersebut berarti jumlah warga miskin yang belum mendapatkan kartu Jamkesmas sebanyak 12.093 orang. Kekurangan tersebut bisa diatasi oleh Jamkeskinda Kota Tasikmalaya.

Walaupun pemerintah Kota Tasikmalaya sudah mengatasi kekurangan kuota Jamkesmas, tetapi fakta yang terjadi di lapangan menunjukkan bahwa masih banyak warga miskin yang tidak mampu belum mendapatkan fasilitas kesehatan ini terjadi karena adanya ketimpangan data yang terjadi di tingkat kelurahan, sehingga ada sebagian masyarakat yang mendapatkan dua kartu Jamkesmas dan Jamkesda. Ini menunjukkan bahwa implementasi Jamkesda masih kurang optimal dan tidak tepat sasaran. Selain itu juga masih ada instansi kesehatan yang memungut biaya pengelolaan darah untuk warga miskin yang tidak mampu, padahal sesuai dengan keputusan Walikota Tasikmalaya bahwa warga miskin dibebaskan dari semua biaya apapun dalam pelayanan kesehatan. 
Jumlah keluarga miskin yang berada di Kota Tasikmalaya tiap tahunnya meningkat, pada tahun 2011 jumlah keluarga miskin sebanyak 6.844 orang, tahun 2012 sebanyak 153.197 orang, sedangkan pada tahun 2013 sebanyak 228.781. Dari jumlah keluarga miskin tersebut pemerintah Kota Tasikmalaya mengeluarkan anggaran biaya untuk program Jamkesda pada tahun 2010 sebesar Rp. 5.450.000.000, tahun $2011 \mathrm{Rp}$. 6.575.777.000, sedangkan pada tahun 2012 sebesar Rp. 8.694.464.805. Selain mengeluarkan biaya sendiri pemerintah Kota Tasikmalaya mendapatkan sumber dana APBD Propinsi Jawa Barat pada tahun 2010 sebesar Rp. 2,2 miliar, tahun 2011 sebesar Rp. 2,2 miliar dan pada tahun 2012 sebesar Rp. 2,1 miliar.

Anggaran yang dikeluarkan oleh Pemerintah Kota Tasikmalaya untuk Program Jamkesda ternyata belum mampu mencukupi kebutuhan biaya kesehatan bagi warga miskin di Kota Tasikmalaya, masih banyaknya warga miskin yang belum mendapatkan pelayanan kesehatan yang gratis dari pemerintah, bahkan pada tahun 2012 pemerintah Kota Tasikmalaya menunggak ke Rumah Sakit Umum Tasikmalaya yang jumlahnya sangat besar. Selain adanya tunggakan, tidak terpenuhinya layanan kesehatan gratis bagi warga miskin ini disebabkan karena banyak ditemukan warga miskin yang mempunyai kartu kesehatan ganda, sehingga warga miskin lain tidak memperoleh kartu layanan gratis. Sarana dan prasarana pun menjadi salah satu persoalan tidak terlayaninya masyarakat miskin dalam pelayanan kesehatan seperti kurangnya tempat perawatan yang terbatas di Rumah Sakit, sehingga banyak pasien Jamkesda yang menggunakan tempat transit, sehingga membuat ketidaknyamanan bagi keluarga atau penunggu pasien yang dapat mengakibatkan keluarga atau penunggu pasien terpapar penyakit.

Dengan adanya program jaminan kesehatan bagi masyarakat miskin sangat membantu bagi mereka yang membutuhkan biaya pengobatan bagi rawat jalan maupun rawat inap, terutama bagi mereka yang akan menjalani tindakan operasi yang membutuhkan biaya yang cukup mahal, dengan adanya Jamkesda masyarakat dapat menjalani tindakan tersebut dengan tidak membayar. Untuk meningkatkan pelayanan kesehatan yang gratis bagi warga miskin perlu dibuat suatu kebijakan agar seluruh warga miskin khususnya yang ada di Kota Tasikmalaya mendapatkan layanan kesehatan gratis.

Dalam pelaksanaan program Jaminan Kesehatan Daerah di Kota Tasikmalaya memang masih banyak menghadapi kendala-kendala baik secara internal maupun eksternal. Berbagai permasalahan masih sering ditemui terkait dengan kebijakan tersebut, baik karena kurang siapnya kelembagaan pengelola maupun ketersediaan anggaran untuk menjalankan program dengan baik. Masalah-masalah tersebut semula diharapkan akan memperoleh bantuan dari pemerintah daerah. Namun secara umum, distribusi tersebut sulit diperoleh karena keterbatasan-keterbatasan dana pemerintah daerah.

Sehubungan dengan kebijakan tersebut dalam mengimplementasikan suatu kebijakan diperlukan hal-hal seperti yang dikatakan (Edwards, 1980), dalam menjalankan kebijakan perlu memperhatikan empat isu pokok agar implementasi 
kebijakan menjadi efektif, yaitu communication, resource, disposition or attitudes, dan bureaucratic structures

Implementasi kebijakan sebagaimana pendapat Howelett dan Rames (1960:45 dalam Teguh Yuwono, 2002:8) adalah mentransfer kebijakan ke dalam program dan tindakan aksi sehingga membutuhkan berbagai kondisi yang berkaitan dengan bentuk masalah yang hendak dipecahkan dengan implementasi kebijakan itu sendiri, kondisi lingkungan yang ikut mempengaruhi implementasi, organisasi pelaksanaan dan sumber daya pelaksanaan serta sumber daya yang beralokasi.

Sementara menurut Paters Hufen dan Nispen (1998:34) dalam (Soesilowati \& Sucihatiningsih, 2016) melihat implementasi kebijakan mengandung unsur-unsur berdasarkan instrumen kebijakan yang meliputi antara lain adalah : (1) sistem karier pegawai, teknik medis (dokter, bidan, perawat) atau memberikan sistem kenyamanan dan keamanan pasien, dan memberikan pelayanan kesehatan yang lebih baik, lebih cepat dan lebih akurat, lebih baru, serta sesuai dengan harapan pelanggan/pasien. Rakyat adalah pemilik ditujukan pada seperangkat nilai yang menjadi dasar tindakan para pihak yang terlibat dalam implementasi. (2) Jaringan kerja, baik secara personal maupun institusi di dalam dan luar negeri. Guna memenuhi tuntutan reformasi pelayanan atau birokrasi. Menurut pandangan Islami (2007:26), "dalam hal ini birokrasi tidak hanya bertanggung jawab yuridis formal tetapi juga bertanggung jawab moral" dan sumber kekuatan dan lain-lain yang ditujukan pada seperangkat nilai yang menjadi dasar tindakan bagi para pihak yang terlibat dalam implementasi kebijakan.

Selain instrumen sebagaimana disebutkan di atas implementasi menurut Lester dan Stewart (2000) dalam (Mulyadi, 2015) juga membutuhkan kejelasan dari pihak yang akan melaksanakan kebijakan itu dan pilihan pada teknik implementasi. Pendekatan pertama pada seputar siapa melaksanakan pelaksana atau para pihak yang terlibat dalam implementasi untuk menerapkan standar pelayanan kesehatan, sistem pengawasan, pemberian sanksi dan hukuman, berdasarkan pada upaya persuasif yang memberikan kebebasan kepada pelaksana atau para pihak yang terlibat untuk mengikuti atau tidak mengikuti mekanisme yang sudah digariskan disertai dengan konsekuensi logis pilihan mereka.

Menghadapi permasalahan kesehatan dengan multi aspek sebagaimana telah dijelaskan di atas maka jelaslah bahwa sehebat apapun sebuah implementasi kebijakan dirumuskan dan diimplementasikan, termasuk kebijakan sektor pelayanan kesehatan yang diharapkan berdampak pada kualitas hidup masyarakat, akan tidak semudah yang dibayangkan. Hal ini karena beragamnya aspek kesehatan itu sendiri yang kemudian berhadapan dengan berbagai publik interest sejak policy process berlangsung, tetapi juga perubahan arah kebijakan sering terjadi pada setiap periode pergantian kepemimpinan termasuk instabilitas politik pasca orde baru.

Selain itu juga permasalahan-permasalahan dalam penyaluran dana Jaminan Kesehatan Daerah di Kota Tasikmalaya adalah : kurangnya sosialisasi penggunaan kartu Jaminan Kesehatan Daerah, pendataan keluarga miskin kurang akurat sehingga tidak tepat sasaran, banyak kartu tanda penduduk yang double, nama tidak sesuai dengan 
identitas lain $(\mathrm{KTP}+\mathrm{KK})$, dan sarana di rumah sakit belum menunjang. Berbagai permasalahan di bidang kesehatan sebagaimana dipaparkan di atas adalah yang dialami oleh pihak Dinas Kesehatan maupun masyarakat Tasikmalaya.

\section{Metode Penelitian}

Penelitian ini diarahkan untuk mendeskripsikan dan menganalisis secara mendalam tentang pengaruh implementasi kebijakan Jamkesda terhadap pelayanan kesehatan masyarakat miskin pada Dinas Kesehatan Kota Tasikmalaya. Penelitian ini menggunakan metode deskriptif analisis yaitu melakukan penelitian terhadap kenyataan-kenyataan yang tengah berlangsung yang merupakan suatu masalah yang harus segera diatasi. Sejalan dengan pendapat (Komariah, 2012) bahwa pada umumnya persamaan sifat dan segala bentuk penyelidikan deskriptif ini menuturkan dan menafsirkan data yang ada, seperti situasi yang dialami, hubungan kegiatan dan pandangan terhadap proses yang sedang terjadi.

\section{Hasil dan Pembahasan}

Analisis data menggunakan analisis jalur (path analisis) dengan bantuan SPSS Versi 17.0. Hasil penelitian yang diperoleh kemudian dianalisis untuk melihat :

1. Pengaruh variabel $X_{1}$ (komunikasi) terhadap variabel $Y$ (kualitas pelayanan) di Dinas Kesehatan Kota Tasikmalaya.

2. Pengaruh variabel $X_{2}$ (sumber daya) terhadap variabel $Y$ (kualitas pelayanan) di Dinas Kesehatan Kota Tasikmalaya.

3. Pengaruh variabel $\mathrm{X}_{3}$ (disposisi) terhadap variabel $\mathrm{Y}$ (kualitas pelayanan) di Dinas Kesehatan Kota Tasikmalaya.

4. Pengaruh variabel $\mathrm{X}_{4}$ (struktur birokrasi) terhadap variabel $\mathrm{Y}$ (kualitas pelayanan) di Dinas Kesehatan Kota Tasikmalaya.

5. Pengaruh variabel komunikasi, sumber daya, disposisi, dan struktur birokrasi terhadap variabel kualitas pelayanan di Dinas Kesehatan Kota Tasikmalaya.

Pengaruh komunikasi terhadap kualitas pelayanan kesehatan masyarakat miskin pada Dinas Kesehatan Kota Tasikmalaya dapat dilihat dari indikator yang digunakan yaitu : transformasi, kejelasan, dan konsistensi

Untuk menguji hipotesis diatas maka dilakukan pengolahan atas data, dimana berdasarkan hasil perhitungan pada lampiran didapat nilai koefisien jalur $\rho_{Y X 1}$ sebesar 0,238 . Untuk dapat mengetahui besarnya pengaruh komunikasi terhadap kualitas pelayanan kesehatan dilakukan perhitungan pengaruh langsung dan pengaruh tidak langsung komunikasi terhadap kualitas pelayanan kesehatan yang penulis sajikan dalam Tabel 1. 
Tabel 1

Analisis Pengaruh Komunikasi Terhadap Kualitas Pelayanan Kesehatan Pada Dinas Kesehatan Kota Tasikmalaya

\begin{tabular}{clc}
\hline No. & \multicolumn{1}{c}{ Uraian } & Total Pengaruh \\
\hline 1 & $\begin{array}{l}\text { Pengaruh Langsung } \\
\mathrm{Y} \leftarrow \mathrm{X}_{1} \rightarrow \mathrm{Y}=(0,238)^{2}\end{array}$ & 0.057 \\
\hline 2 & $\begin{array}{l}\text { Pengaruh Tidak Langsung } \\
\mathrm{Y} \leftarrow \mathrm{X}_{1} \rightarrow \mathrm{X}_{2} \rightarrow \mathrm{Y}_{2} \\
(0,238.0,357.0,264)\end{array}$ & 0.022 \\
\hline 3 & $\begin{array}{l}\mathrm{Y} \leftarrow \mathrm{X}_{1} \rightarrow \mathrm{X}_{3} \rightarrow \mathrm{Y}_{3} \\
(0,238.0,509.0,248)\end{array}$ & 0,030 \\
\hline 4 & $\begin{array}{l}\mathrm{Y} \leftarrow \mathrm{X}_{1} \rightarrow \mathrm{X}_{4} \rightarrow \mathrm{Y}_{4} \\
(0,238.0,284.0,217)\end{array}$ & 0,015 \\
\hline Total pengaruh $\mathrm{X}_{1}$ terhadap $\mathrm{Y}$ & $\mathbf{0 , 1 2 4}$ \\
\hline
\end{tabular}

Pada Tabel 1 menunjukkan bahwa pengaruh langsung komunikasi terhadap kualitas pelayanan kesehatan $\left(\rho_{\mathrm{YX} 1}\right)^{2}$ sebesar 0,057 sedangkan pengaruh tidak langsung yang melalui sumber daya sebesar 0,022, melalui disposisi sebesar 0,030, dan struktur birokrasi sebesar 0,015 sehingga total pengaruh komunikasi terhadap kualitas pelayanan kesehatan sebesar 0,124. Dengan demikian dapat diketahui bahwa komunikasi berpengaruh terhadap kualitas pelayanan kesehatan sebesar 12,4\%.

Dengan kriteria penolakan Ho jika $-\mathrm{t}^{1} / 2 \alpha>\mathrm{t}_{\text {hitung }}$ atau $\mathrm{t}_{\text {hitung }}>\mathrm{t}^{1} / 2 \alpha$, maka dengan koefisien beta $(\beta)=0,238$, diperoleh nilai thitung sebesar 2,222 (lampiran 5) dengan mengambil taraf signifikansi $\alpha$ sebesar $5 \%$, maka nilai $\mathrm{t}_{\text {tabel }} 2,000$, sehingga $-\mathrm{t}^{1} / 2 \alpha \geq$ $t_{\text {hitung }} \geq \mathrm{t}^{1 / 2} \alpha$ maka terima Ho atau dengan kata lain komunikasi berpengaruh terhadap kualitas pelayanan kesehatan.

Pengaruh sumber daya terhadap kualitas pelayanan kesehatan masyarakat miskin pada Dinas Kesehatan Kota Tasikmalaya dapat dilihat dari indikator yang digunakan yaitu : sumber daya manusia, sumber daya anggaran, sumber daya peralatan, dan sumber daya informasi dan kewenangan.

Untuk menguji hipotesis diatas maka dilakukan pengolahan atas data, dimana berdasarkan hasil perhitungan pada lampiran didapat nilai koefisien jalur $\rho_{Y X 2}$ sebesar 0,264. Untuk dapat mengetahui besarnya pengaruh sumber daya terhadap kualitas pelayanan kesehatan dilakukan perhitungan pengaruh langsung dan pengaruh tidak langsung sumber daya terhadap kualitas pelayanan kesehatan yang penulis sajikan dalam Tabel 2. 
Tabel 2

Analisis Pengaruh Sumber Daya Terhadap Kualitas Pelayanan Kesehatan

Pada Dinas Kesehatan Kota Tasikmalaya

\begin{tabular}{clc}
\hline No. & \multicolumn{1}{c}{ Uraian } & Total Pengaruh \\
\hline 1 & $\begin{array}{l}\text { Pengaruh Langsung } \\
\mathrm{Y} \leftarrow \mathrm{X}_{2} \rightarrow \mathrm{Y}=(0,264)^{2}\end{array}$ & 0.070 \\
\hline 2 & $\begin{array}{l}\text { Pengaruh Tidak Langsung } \\
\mathrm{Y} \leftarrow \mathrm{X}_{2} \rightarrow \mathrm{X}_{3} \rightarrow \mathrm{Y}_{3} \\
(0,264.0,496.0,248)\end{array}$ & 0.032 \\
\hline 3 & $\begin{array}{l}\mathrm{Y} \leftarrow \mathrm{X}_{2} \rightarrow \mathrm{X}_{4} \rightarrow \mathrm{Y}_{4} \\
(0,264.0,197.0,217)\end{array}$ & 0.011 \\
\hline 4 & $\begin{array}{l}\mathrm{Y} \leftarrow \mathrm{X}_{2} \rightarrow \mathrm{X}_{1} \rightarrow \mathrm{Y}_{1} \\
(0,264.0,357.0,238)\end{array}$ & 0.022 \\
\hline Total pengaruh $\mathrm{X}_{1}$ terhadap $\mathrm{Y}$ & $\mathbf{0 , 1 3 6}$ \\
\hline
\end{tabular}

Pada Tabel 2 menunjukkan bahwa pengaruh langsung sumber daya terhadap kualitas pelayanan kesehatan $\left(\rho_{Y X 2}\right)^{2}$ sebesar 0,070 sedangkan pengaruh tidak langsung yang melalui disposisi sebesar 0,032, melalui struktur birokrasi sebesar 0,011, dan melalui komunikasi sebesar 0,022 sehingga total pengaruh sumber daya terhadap kualitas pelayanan kesehatan sebesar 0,136. Dengan demikian dapat diketahui bahwa sumber daya berpengaruh terhadap kualitas pelayanan kesehatan sebesar 13,6\%.

Dengan kriteria penolakan Ho jika $-\mathrm{t}^{1} 1 / 2 \alpha>\mathrm{t}_{\text {hitung }}$ atau $\mathrm{t}_{\text {hitung }}>\mathrm{t}^{1} / 2 \alpha$, maka dengan koefisien beta $(\beta)=0,264$, diperoleh nilai thitung sebesar 2,516 (lampiran 5) dengan mengambil taraf signifikansi $\alpha$ sebesar $5 \%$, maka nilai tabel 2,000, sehingga $-t^{1} \frac{2}{2} \alpha \geq$ $t_{\text {hitung }} \geq \mathrm{t}^{1} / 2 \alpha$ maka terima Ho atau dengan kata lain sumber daya berpengaruh terhadap kualitas pelayanan kesehatan.

Pengaruh disposisi terhadap kualitas pelayanan kesehatan masyarakat miskin pada Dinas Kesehatan Kota Tasikmalaya dapat dilihat dari indikator yang digunakan yaitu : pengetahuan, pemahaman dan pendalaman terhadap kebijakan, arah respons, menerima, menolak atau netral, dan intensitas terhadap kebijakan

Untuk menguji hipotesis diatas maka dilakukan pengolahan atas data, dimana berdasarkan hasil perhitungan pada lampiran didapat nilai koefisien jalur $\rho_{Y X 3}$ sebesar 0,248 .

Dengan kriteria penolakan Ho jika $-\mathrm{t}^{1} 1 / 2 \alpha>t_{\text {hitung }}$ atau $t_{\text {hitung }}>\mathrm{t}^{1} / 2 \alpha$, maka dengan koefisien beta $(\beta)=0,248$, diperoleh nilai thitung sebesar 2,112 (lampiran 5) dengan mengambil taraf signifikansi $\alpha$ sebesar $5 \%$, maka nilai tabel 2,000, sehingga $-\mathrm{t}^{1 / 2} \alpha \geq$ $\mathrm{t}_{\text {hitung }} \geq \mathrm{t}^{1} / 2 \alpha$ maka terima Ho atau dengan kata lain disposisi berpengaruh terhadap kualitas pelayanan kesehatan.

Pengaruh struktur birokrasi terhadap kualitas pelayanan kesehatan masyarakat miskin pada Dinas Kesehatan Kota Tasikmalaya dapat dilihat dari indikator yang digunakan yaitu : prosedur operasi standar dan fragmentasi yang berasal dari organisasi.

Untuk menguji hipotesis diatas maka dilakukan pengolahan atas data, dimana berdasarkan hasil perhitungan pada lampiran didapat nilai koefisien jalur $\rho_{Y X 4}$ sebesar 
0,217 . Untuk dapat mengetahui besarnya pengaruh struktur birokrasi terhadap kualitas pelayanan kesehatan dilakukan perhitungan pengaruh langsung dan pengaruh tidak langsung struktur birokrasi terhadap kualitas pelayanan kesehatan yang penulis sajikan dalam Tabel 3.

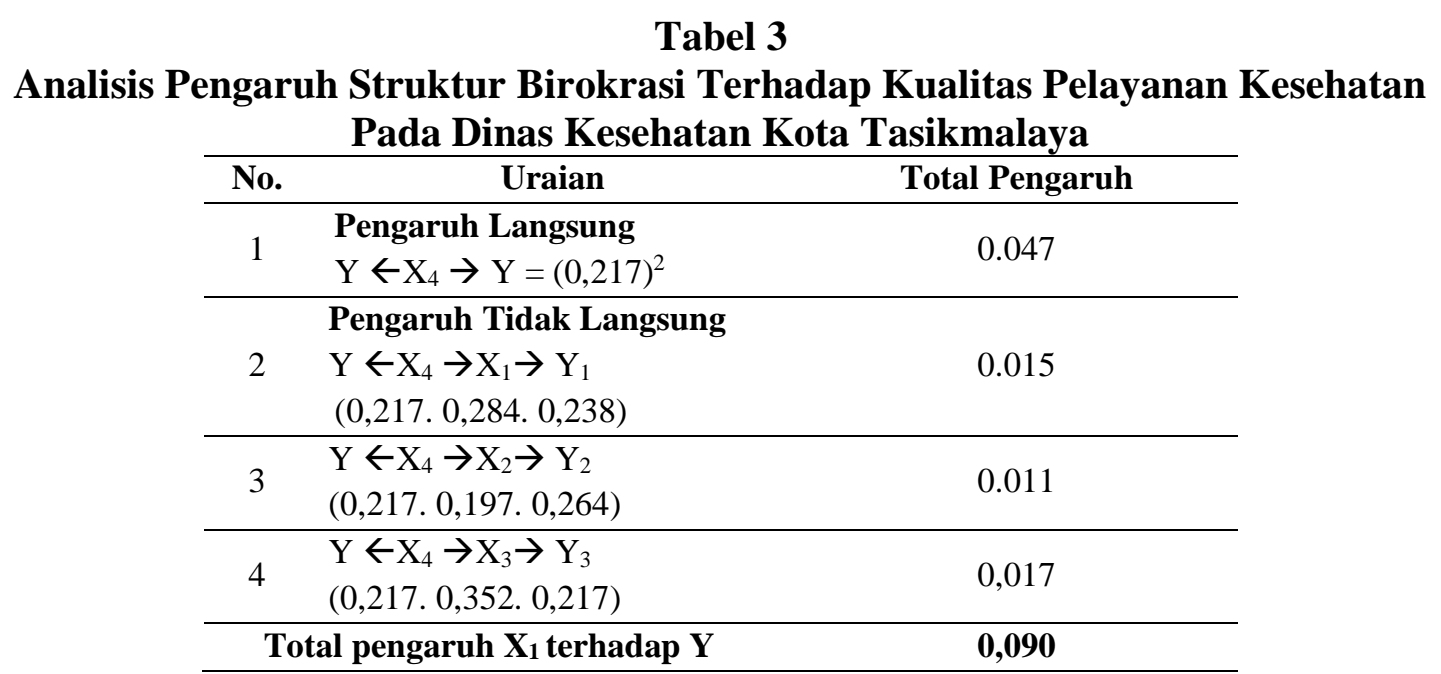

Pada Tabel 3 menunjukkan bahwa pengaruh langsung struktur organisasi terhadap kualitas pelayanan kesehatan $\left(\rho_{\mathrm{YX}}\right)^{2}$ sebesar 0,047 sedangkan pengaruh tidak langsung yang melalui komunikasi sebesar 0,015, melalui disposisi sebesar 0,011, dan melalui struktur birokrasi sebesar 0,017 sehingga total pengaruh struktur birokrasi terhadap kualitas pelayanan kesehatan sebesar 0,090. Dengan demikian dapat diketahui bahwa struktur birokrasi berpengaruh terhadap kualitas pelayanan kesehatan sebesar $9,0 \%$.

Dengan kriteria penolakan Ho jika $-t^{1} 1 / 2 \alpha>t_{\text {hitung }}$ atau thitung $>t^{1} / 2 \alpha$, maka dengan koefisien beta $(\beta)=0,217$, diperoleh nilai thitung sebesar 2,227 (lampiran 5) dengan mengambil taraf signifikansi $\alpha$ sebesar $5 \%$, maka nilai tabel 2,000 , sehingga $-t^{1} / 2 \alpha \geq$ $t_{\text {hitung }} \geq \mathfrak{t}^{1} / 2 \alpha$ maka terima Ho atau dengan kata lain disposisi berpengaruh terhadap kualitas pelayanan kesehatan.

Pengujian hipotesis "pengaruh Implementasi Kebijakan (Komunikasi, Sumber daya, Disposisi, dan Struktur birokrasi) Terhadap Kualitas Pelayanan Kesehatan di Dinas Kesehatan Kota Tasikmalaya" tersebut menggunakan uji F yaitu untuk menguji apakah terdapat pengaruh secara signifikan antara Implementasi Kebijakan (Komunikasi, Sumber daya, Disposisi, dan Struktur birokrasi) Terhadap Kualitas Pelayanan Kesehatan di Dinas Kesehatan Kota Tasikmalaya, dimana hasil dan pengolahan data melalui SPSS versi 17.0.

Untuk pengujian hipotesis dilakukan pengolahan data, dimana dari hasil

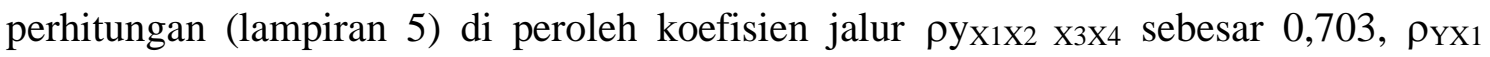

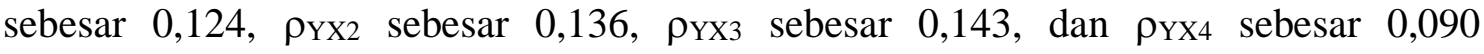
dilakukan analisis melalui pengaruh langsung dan tidak langsung pada tabel 4 . 


\section{Tabel 4}

Analisis Pengaruh Implementasi Kebijakan (Komunikasi, Sumber daya, Disposisi, dan Struktur birokrasi) Terhadap Kualitas Pelayanan Kesehatan di Dinas

Kesehatan Kota Tasikmalaya

\begin{tabular}{|c|c|c|}
\hline No. & Uraian & Total Pengaruh \\
\hline 1 & $\begin{array}{l}\text { Pengaruh Langsung } \\
\mathrm{Y} \leftarrow \mathrm{X}_{1} \rightarrow \mathrm{Y}=(0,238)^{2}\end{array}$ & 0.057 \\
\hline 2 & $\begin{array}{l}\text { Pengaruh Tidak Langsung } \\
\mathrm{Y} \leftarrow \mathrm{X}_{1} \rightarrow \mathrm{X}_{2} \rightarrow \mathrm{Y}_{2} \\
(0,238.0,357.0,264)\end{array}$ & 0.022 \\
\hline 3 & $\begin{array}{l}\mathrm{Y} \leftarrow \mathrm{X}_{1} \rightarrow \mathrm{X}_{3} \rightarrow \mathrm{Y}_{3} \\
(0,238.0,509.0,248)\end{array}$ & 0,030 \\
\hline 4 & $\begin{array}{l}\mathrm{Y} \leftarrow \mathrm{X}_{1} \rightarrow \mathrm{X}_{4} \rightarrow \mathrm{Y}_{4} \\
(0,238.0,284.0,217)\end{array}$ & 0,015 \\
\hline \multicolumn{2}{|c|}{ Total pengaruh $\mathrm{X}_{1}$ terhadap $\mathrm{Y}$} & $\mathbf{0 , 1 2 4}$ \\
\hline 5 & $\begin{array}{l}\text { Pengaruh Langsung } \\
\mathrm{Y} \leftarrow \mathrm{X}_{2} \rightarrow \mathrm{Y}=(0,264)^{2}\end{array}$ & 0.070 \\
\hline 6 & $\begin{array}{l}\text { Pengaruh Tidak Langsung } \\
\mathrm{Y} \leftarrow \mathrm{X}_{2} \rightarrow \mathrm{X}_{3} \rightarrow \mathrm{Y}_{3} \\
(0,264.0,496.0,248)\end{array}$ & 0.032 \\
\hline 7 & $\begin{array}{l}\mathrm{Y} \leftarrow \mathrm{X}_{2} \rightarrow \mathrm{X}_{4} \rightarrow \mathrm{Y}_{4} \\
(0,264.0,197.0,217)\end{array}$ & 0.011 \\
\hline 8 & $\begin{array}{l}\mathrm{Y} \leftarrow \mathrm{X}_{2} \rightarrow \mathrm{X}_{1} \rightarrow \mathrm{Y}_{1} \\
(0,264.0,357.0,238)\end{array}$ & 0.022 \\
\hline \multicolumn{2}{|c|}{ Total pengaruh $\mathrm{X}_{2}$ terhadap $\mathrm{Y}$} & $\mathbf{0 , 1 3 6}$ \\
\hline 9 & $\begin{array}{l}\text { Pengaruh Langsung } \\
\mathrm{Y} \leftarrow \mathrm{X}_{3} \rightarrow \mathrm{Y}=(0,248)^{2}\end{array}$ & 0.062 \\
\hline 10 & $\begin{array}{l}\text { Pengaruh Tidak Langsung } \\
\mathrm{Y} \leftarrow \mathrm{X}_{3} \rightarrow \mathrm{X}_{4} \rightarrow \mathrm{Y}_{4} \\
(0,248.0,352.0,217)\end{array}$ & 0.019 \\
\hline 11 & $\begin{array}{l}\mathrm{Y} \leftarrow \mathrm{X}_{3} \rightarrow \mathrm{X}_{1} \rightarrow \mathrm{Y}_{1} \\
(0,248.0,509.0,238)\end{array}$ & 0.030 \\
\hline 12 & $\begin{array}{l}Y \leftarrow X_{3} \rightarrow X_{2} \rightarrow Y_{2} \\
(0,248.0,496.0,264)\end{array}$ & 0.032 \\
\hline \multicolumn{2}{|c|}{ Total pengaruh $\mathrm{X}_{3}$ terhadap $\mathrm{Y}$} & $\mathbf{0 , 1 4 3}$ \\
\hline 13 & $\begin{array}{l}\text { Pengaruh Langsung } \\
\mathrm{Y} \leftarrow \mathrm{X}_{4} \rightarrow \mathrm{Y}=(0,217)^{2}\end{array}$ & 0.047 \\
\hline 14 & $\begin{array}{l}\text { Pengaruh Tidak Langsung } \\
\mathrm{Y} \leftarrow \mathrm{X}_{4} \rightarrow \mathrm{X}_{1} \rightarrow \mathrm{Y}_{1} \\
(0,217.0,284.0,238)\end{array}$ & 0.015 \\
\hline 15 & $\begin{array}{l}\mathrm{Y} \leftarrow \mathrm{X}_{4} \rightarrow \mathrm{X}_{2} \rightarrow \mathrm{Y}_{2} \\
(0,217.0,197.0,264)\end{array}$ & 0.011 \\
\hline 16 & $\begin{array}{l}\mathrm{Y} \leftarrow \mathrm{X}_{4} \rightarrow \mathrm{X}_{3} \rightarrow \mathrm{Y}_{3} \\
(0,217.0,352.0,217)\end{array}$ & 0,017 \\
\hline Tot & l pengaruh $\mathrm{X}_{4}$ terhadap $\mathrm{Y}$ & $\mathbf{0 , 0 9 0}$ \\
\hline 17 & $\begin{array}{l}\text { Total pengaruh X1, X2, X3, } \\
\text { dan X4 Terhadap Y }\end{array}$ & 0,494 \\
\hline 18 & $\begin{array}{l}\text { Pengaruh faktor residu } \varepsilon \rightarrow \\
\mathbf{Y}=(\mathrm{PY} \varepsilon)^{2}\end{array}$ & 0,506 \\
\hline 19 & Total pengaruh & 1,00 \\
\hline
\end{tabular}

Dari Tabel 4 di atas menunjukkan bahwa pengaruh implementasi Kebijakan (Komunikasi, Sumber daya, Disposisi, dan Struktur birokrasi) Terhadap Kualitas Pelayanan Kesehatan di Dinas Kesehatan Kota Tasikmalaya diperoleh pengaruh sebesar 
0,494 atau 49,4\%, sedangkan pengaruh faktor luar yang tidak termasuk dalam variabel penelitian adalah sebesar 0,506 atau 50,6\%. Faktor tersebut diduga antara lain kompensasi, prestasi kerja, pengawasan langsung maupun tidak langsung, penghargaan, dan lain-lain.

Dari hasil perhitungan SPSS (lampiran 5), diperoleh nilai $F_{\text {hitung }}$ sebesar 15,128 dengan kriteria penolakan $\mathrm{H}_{\mathrm{o}}$, jika $\mathrm{F}_{\text {hitung }}>\mathrm{F}_{\text {tabel}}$, dengan mengambil taraf signifikan $\alpha$ sebesar $5 \%$, maka dari tabel distribusi F- Snedecor diperoleh F $\alpha ; \mathrm{k} ;(\mathrm{n}-\mathrm{k}-1)=67-2$ 1 adalah sebesar 1,34 atau cukup melihat sig F yaitu 0,000 yang artinya dengan $\alpha$ lebih kecil dari $5 \%$ masih menunjukan signifikan.

\section{Kesimpulan}

Berdasarkan hasil penelitian dan pembahasan, maka dapat disimpulkan sebagai berikut :

1. Implementasi kebijakan jaminan kesehatan yang terdiri dari komunikasi, sumber daya, disposisi, dan struktur birokrasi di Dinas Kesehatan Kota Tasikmalaya sudah cukup berjalan dengan optimal, hal ini dapat terlihat dari kategori yang diperoleh dari tanggapan responden ada pada kategori baik.

2. Kualitas pelayanan kesehatan pada masyarakat miskin di Dinas Kesehatan Kota Tasikmalaya sudah baik, hal ini terlihat dari tanggapan responden bahwa kualitas pelayanan yang diberikan oleh petugas sudah baik.

3. Ada pengaruh signifikan implementasi kebijakan jaminan kesehatan daerah terhadap kualitas pelayanan kesehatan masyarakat miskin pada Dinas Kesehatan Kota Tasikmalaya baik secara parsial maupun simultan.

Dinas Kesehatan Kota Tasikmalaya perlu mengevaluasi kebijakan Jamkesmas terutama Pedoman Petunjuk Teknis Pelaksanaan Jamkesmas dan dalam hal kepesertaan, akses, mekanisme pelayanan, pendanaan dan mutu pelayanan. Pemerintah Daerah / Dinas Kesehatan perlu membuat Peraturan Daerah mengenai pelaksanaan Jamkesmas yang mengatur secara terintegratif dan komprehensif tentang kepesertaan, akses, mekanisme pelayanan, pendanaan dan mutu pelayanan, dan perlu membuat kebijakan dan program pengembangan SDM di bidang pelayanan Jamkesmas melalui pendidikan dan pelatihan keterampilan manajemen pelayanan, kursus, seminar, lokakarya, meningkatkan koordinasi dan kerjasama serta pelibatan tokoh masyarakat, tokoh agama dan organisasi sosial dalam pelaksanaan Jamkesmas. 


\section{BIBLIOGRAFI}

Edwards, George C. (1980). Implementing public policy. Congressional Quarterly Press.

Komariah, Siti. (2012). Respons siswa terhadap penggunaan model pembelajaran active learning hubungannya dengan minat belajar siswa pada mata pelajaran IPS: Penelitian di kelas V MI Naelushibyan Cibiru Wetan Cileunyi Bandung. UIN Sunan Gunung Djati Bandung.

Mulyadi, Deddy. (2015). Perilaku organisasi dan kepemimpinan pelayanan. Bandung: Alfabeta.

Naldi, Yandri. (2019). Implementasi Regulasi Pelayanan Medis Bagi Mahasiswa Kedokteran di Rumah Sakit Waled Kabupaten Cirebon. Syntax Literate; Jurnal Ilmiah Indonesia, 4(9), 152-162.

Soesilowati, Etty, \& Sucihatiningsih, D. W. P. (2016). Strategic Policies for Increasing the Competitive Powers of Indonesian Horticultural Products in Asean Markets. 1st Unnes International Conference, 64. 